\title{
Development of Radiometric Assays for Quantification of Enzyme Activities of the Key Enzymes of Thyroid Hormones Metabolism
}

\author{
S. PAVELKA ${ }^{1,2}$ \\ ${ }^{1}$ Department of Radiometry, Institute of Physiology Academy of Sciences of the Czech Republic, \\ Prague, Czech Republic, ${ }^{2}$ Institute of Biochemistry, Faculty of Science, Masaryk University, Brno, \\ Czech Republic
}

Received July 21, 2013

Accepted July 28, 2013

\section{Summary}

We newly elaborated and adapted several radiometric enzyme assays for the determination of activities of the key enzymes engaged in the biosynthesis (thyroid peroxidase, TPO) and metabolic transformations (conjugating enzymes and iodothyronine deiodinases, IDs) of thyroid hormones (THs) in the thyroid gland and in peripheral tissues, especially in white adipose tissue (WAT). We also elaborated novel, reliable radiometric methods for extremely sensitive determination of enzyme activities of IDs of types 1, 2 and 3 in microsomal fractions of different rat and human tissues, as well as in homogenates of cultured mammalian cells. The use of optimized TLC separation of radioactive products from the unconsumed substrates and film-less autoradiography of radiochromatograms, taking advantage of storage phosphor screens, enabled us to determine IDs enzyme activities as low as $10^{-18}$ katals. In studies of the interaction of fluoxetine (Fluox) with the metabolism of THs, we applied adapted radiometric enzyme assays for iodothyronine sulfotransferases (ST) and uridine 5'-diphosphoglucuronyltransferase (UDP-GT). Fluox is the most frequently used representative of a new group of non-tricyclic antidepressant drugs - selective serotonin re-uptake inhibitors. We used the elaborated assays for quantification the effects of Fluox and for the assessment of the degree of potential induction of rat liver ST and/or UDP-GT enzyme activities by Fluox alone or in combination with $T_{3}$. Furthermore, we studied possible changes in IDs activities in murine adipose tissue under the conditions that promoted either tissue hypertrophy (obesogenic treatment) or involution (caloric restriction), and in response to leptin, using our newly developed radiometric enzyme assays for IDs. Our results suggest that deiodinase D1 has a functional role in WAT, with D1 possibly being involved in the control of adipose tissue metabolism and/or accumulation of the tissue. Significant positive correlation between specific enzyme activity of D1 in WAT and plasma leptin levels was found. The newly developed and adapted radiometric enzyme assays proved to be very useful tools for studies of factors modulating THs metabolism, not only in model animals but also in clinical studies of human obesity.

\section{Key words}

Enzyme • Metabolism • Radiometric assay • Thyroid hormone

\section{Corresponding author}

S. Pavelka, Department of Radiometry, Institute of Physiology, Academy of Sciences of the Czech Republic, Vídeňská 1083, 14220 Prague 4, Czech Republic. E-mail: pavelka@biomed.cas.cz

\section{Introduction}

The principle of radiometric enzyme assays is the enzymaticaly-catalyzed conversion of radioactively labeled substrates to labeled products and the measurement of radioactivity of either products or residual substrate after their quantitative separation. The availability of a simple and rapid method for quantitative separation of substrate and product is one of the two major requirements of a radiometric enzyme assay. The other requirement is the availability of a suitable labeled substrate of known specific radioactivity (Pavelka 2010a).

Thyroid hormones (THs), the secretory products of the thyroid gland, are simple substances 
iodothyronines, which are derived from the iodinated residues of the amino acid tyrosine (Fig. 1). THs represent one of the major endocrine regulators and are potent modulators of cellular development, growth and differentiation. These substances are essential for normal development and function of all organs and tissues. The most important from several known iodothyronines are 3,5,3',5'-tetraiodo-L-thyronine or thyroxine $\left(\mathrm{T}_{4}\right)$ and 3,5,3'-triiodo-L-thyronine $\left(T_{3}\right)$. In fact, $T_{4}$ is a prohormone, a precursor of biologically more active $T_{3}$, which binds to specific nuclear THs receptors with the highest affinity. All the thyroxine is biosynthesized in the thyroid gland, under the catalysis of the key enzyme thyroid peroxidase. On the contrary, at least $80 \%$ of the circulating $\mathrm{T}_{3}$ is produced in peripheral tissues by deiodination of local $\mathrm{T}_{4}$ (Braverman and Utiger 1996). A number of metabolic transformations of $\mathrm{THs}-$ iodothyronines molecules have been described, the most important of which are stepwise mono-deiodinations (Leonard and Kohrle 2000) and glucuronide and sulfate conjugations of phenolic hydroxyl group of THs (Braverman and Utiger 1996) (Fig. 1).

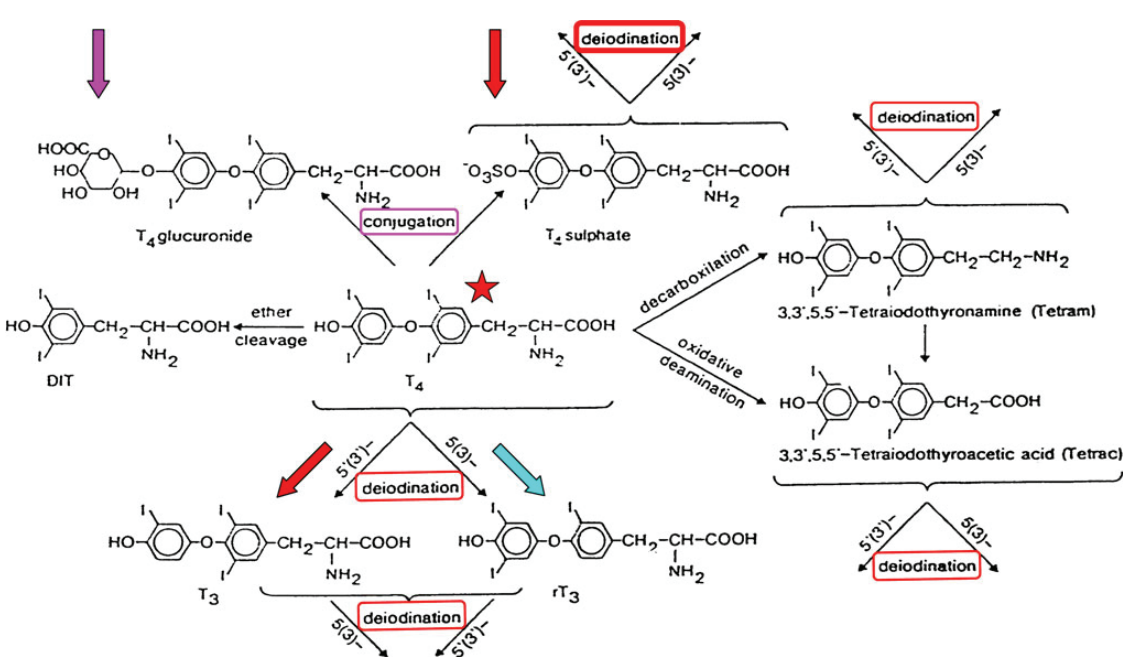

Fig. 1. Enzymatic biotransformations of iodothyronines, especially of thyroid hormones (THs) 3,5,3', $5^{\prime}$-tetraiodo-Lthyronine (thyroxine, $\mathrm{T}_{4}$ ) and 3,5,3'triiodo-L-thyronine $\left(T_{3}\right)$ in peripheral tissues. The most important of these reactions are stepwise monodeiodinations and glucuronide and sulfate conjugations of phenolic hydroxyl groups of THs.
One of the most important targets for THs is the adipose tissue. However, the metabolism of THs in white adipose tissue is poorly characterized (Obregon 2008, Ortega et al. 2012). The accumulation of body fat could be affected by influencing the capacity of fat cells to proliferate and differentiate, and by modulating the metabolism of adipocytes. THs together with other hormones, pharmacological agents and nutrients could affect adiposity, suggesting novel therapeutic strategies for obesity treatment (Kopecký et al. 2004).

\section{Elaboration of radiometric enzyme assay for thyroid peroxidase}

Thyroid peroxidase (TPO) is a membrane-bound enzyme responsible in the thyrocytes for oxidation of the trapped iodide and for binding of resulting iodine to a few specific tyrosine residues, bound in a large glycoprotein thyroglobulin. The immediate oxidant (electron acceptor) for this reaction is hydrogen peroxide. Produced bound mono- and diiodotyrosine residues then undergo oxidative condensation to form $\mathrm{T}_{4}$ and $\mathrm{T}_{3}$, along with traces of biologically inactive 3,3',5'-triiodothyronine, reverse $T_{3}\left(\mathrm{rT}_{3}\right)$, respectively. This coupling reaction is also catalyzed by TPO (Braverman and Utiger 1996).

Recently, we have documented in the rat (Pavelka 2009a,b) that an enhanced intake of bromide, along with another inorganic goitrogenic agent perchlorate, could interfere with the metabolism of iodine at the whole-body level. We have also verified the existence of a mutual bromide-iodide interaction in the thyroid gland (Pavelka et al. 2008). Excessive bromide and perchlorate ions in the diet could substantially extend the adverse effects caused by feeding iodine-deficient diets (Pavelka 2004). Mechanism(s) of bromide interference with the biosynthesis of thyroid hormones, however, have not been so far elucidated. Van Leeuwen et al. (1988) stated that excessive exogenous bromide inhibited the TPO activity in the rat. However, Taurog and Dorris (1991) disproved this hypothesis by the results of their in vitro experiments with isolated TPO. To follow thyrotoxic effects of bromide and perchlorate ions and their influence on TPO activity in the rat thyroids, we adapted the procedure (Nakashima and Taurog 1978) of 
the radiometric assay for TPO in vitro. First, we established correct assay conditions. The elaborated radiometric assay for quantification of TPO enzyme activity (Pavelka 2012) was based on the ability of TPO in samples of microsomal fractions of the rat thyroid glands to oxidize supplied ${ }^{131} \mathrm{I}$-iodide in the presence of $\mathrm{H}_{2} \mathrm{O}_{2}$, generated in situ by glucose oxidase, and to catalyze subsequent iodination of specific tyrosyl residues in the added pig thyroglobulin. The measure of TPO activity was the amount of radioiodine incorporated into thyroglobulin. The incorporated portion was determined by the measurement of ${ }^{131}$ I radioactivity in the separated fractions. Either by quantification of radiochromatograms after TLC separation of the unused ${ }^{131}$ I-iodide in aliquots of the incubated reaction mixtures containing measured samples or simply after the precipitation of radiolabeled thyroglobulin with an excess of $10 \%$ trichloroacetic acid and separation of the sediment by brief centrifugation. Both procedures gave practically the same results: The average ratio of the $\%$ of radio-iodine incorporated $\pm \mathrm{SD}$ was $1.00 \pm 0.02$ for 20 samples of microsomal fractions of the thyroids, determined either by the TLC or the precipitation methods.

The use of the elaborated radiometric assay for TPO (Pavelka 2012) revealed a divergent influence of similar goitrogenic agents, bromide and perchlorate ions, on the TPO activity in the rat thyroids (Fig. 2). Excessive bromide exerted a biphasic effect, depending on the extent of bromide intake in the animals (but also on iodine intake; compare the iodine-sufficient diet $\mathrm{B} v s$. iodine-deficient diet $\mathrm{R}$ in Figure 2). In contrast, elevated TPO activities were found in all the rats that were administered with high amounts of perchlorate (not shown).
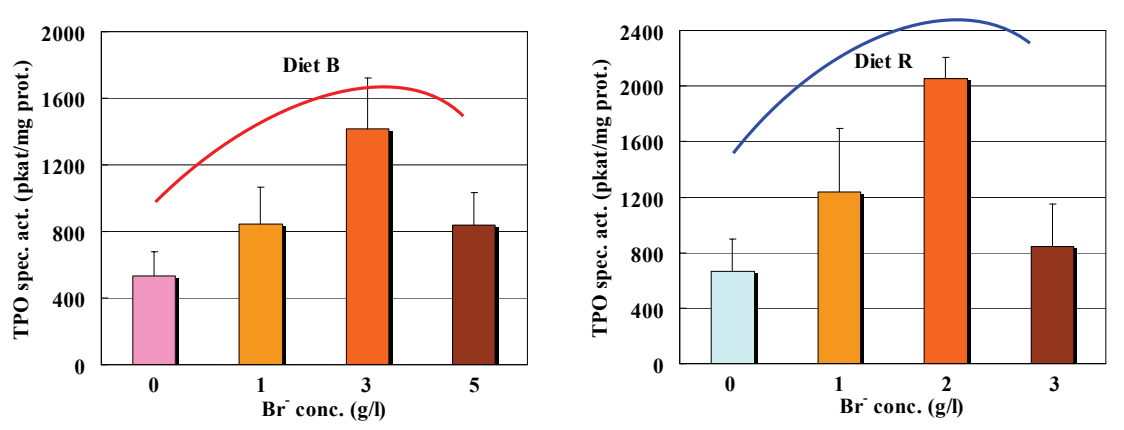

Fig. 2. Specific thyroid peroxidase (TPO) activity, determined by the radiometric enzyme assay in microsomal fractions of the thyroid glands of rats maintained for up to 56 days on the iodine-sufficient diet $B$ or iodine-deficient diet $R$, in dependence on the extent of bromide intake. The rats permanently drank solutions of bromide with the concentrations of $0,1,2,3$ or $5 \mathrm{~g} / \mathrm{l}$.

\section{Novel radiometric enzyme assays for iodothyronine deiodinases}

The most important metabolic transformations of THs - stepwise mono-deiodinations are catalyzed by the enzymes iodothyronine deiodinases (IDs). Three distinct types of IDs have been defined, based on substrate specificity, selectivity of the reactions they catalyze, sensitivity to inhibition by propylthiouracil, and response in activity that occurs in vivo with a change of thyroid status. All three IDs of types 1, 2 and 3 (D1, D2 and D3, respectively) are integral membrane selenoproteins that require thiols as a cofactor (Kohrle 2002). The enzymatic conversion of prohormone $\mathrm{T}_{4}$ by outer-ring 5'-deiodination to most active $\mathrm{T}_{3}$ is catalyzed by $\mathrm{D} 1$ and/or D2. D1 is mainly present in the liver, kidney, thyroid gland and pituitary; due to its high specific activity, hepatic D1 is considered the most important source of circulating $T_{3}$. In turn, its activity is regulated by circulating $T_{3}$. In the brain, this activating reaction is catalyzed mainly by type 2 iodothyronine 5 '-deiodinase. $\mathrm{D} 2$ is predominantly present in pituitary, brain and brown adipose tissue and is essential to the local generation of $\mathrm{T}_{3}$ in the tissues (for references see Pavelka et al. 1997). At the same time, both $\mathrm{T}_{4}$ and $\mathrm{T}_{3}$ in the brain and all other organs and tissues are inactivated by 5 -deiodination on the inner tyrosyl ring. This reaction is catalyzed by type 3 (D3) iodothyronine 5-deiodinase. However, D1 also catalyzes inner-ring 5-deiodination of $\mathrm{T}_{4}$ to produce reverse $\mathrm{T}_{3}$, and 5-deiodination of $\mathrm{T}_{3}$ producing 3,3'-diiodothyronine, both products being inactive forms of THs (Pavelka 2010a).

The measurements of enzyme activity in most of the previous studies examining IDs in different tissues and species were not performed under the proper conditions. A critical prerequisite for performing valid enzyme assay is the correct choice of conditions that are necessary for determination of the initial velocity of substrate conversion. It means, for example, to keep sufficient substrate $v s$. enzyme concentration ratios 
(>1000:1) allowing determination of true activities, where enzyme is acting as catalyst and not as stoichiometric reactant. Recently, we elaborated novel, reliable radiometric methods for extremely sensitive determination of enzyme activities of all three types of IDs in microsomal fractions of different rat and human tissues, as well as in homogenates of cultured mammalian cells (Pavelka 2010a). First, we had to find out the optimum assay conditions for measuring D1, D2 and D3 deiodinase activities, including the concentrations of radioactively labeled substrates and thiol cofactor, the amount of total protein and enzyme concentration in the incubation mixtures, and appropriate incubation times. The novelty of our approach to radiometric enzyme assays consisted in: 1) The use of an optimized solvent system for rapid TLC separation (instead of previously used time-consuming paper chromatography or imperfect ion-exchange chromatography) of radioactive products from the unconsumed, chemically very similar substrates - ${ }^{125}$ I-labeled iodothyronines of high specific radioactivity; 2) the evaluation of obtained radiochromatograms by film-less autoradiography using storage phosphor screens (for examples see Figures 3 and 4). The radioactivity in the individual spots of separated ${ }^{125}$ I-labeled compounds was quantified with a BAS-5000 (Fujifilm Life Science Co.) laser scanner. The elaborated methods proved to be extremely sensitive, enabling to determine IDs enzyme activities as low as $10^{-18}$ katals. At the same time, the assays were rapid, reliable and robust (Pavelka 2010a).

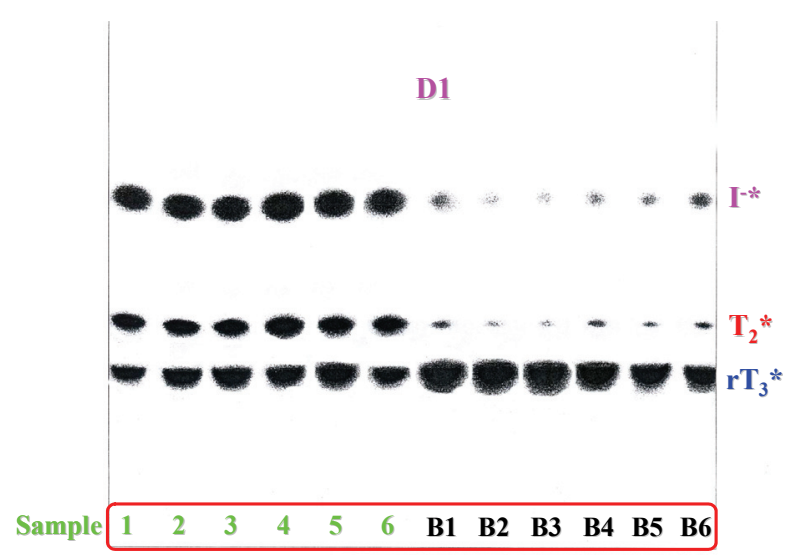

Fig. 3. Electronic image (made with BAS-5000 laser scanner) of radiochromatogram of incubation mixtures (Samples 1-6 and corresponding Blanks B1-B6) in iodothyronine deiodinase D1 assay. The radioactively labeled substrate was $\left[{ }^{125} \mathrm{I}\right]-\mathrm{rT}_{3}$ and labeled products of its enzymatic conversion were $\left[{ }^{125} \mathrm{I}\right]-\mathrm{T}_{2}$ and $\left[{ }^{125} \mathrm{I}\right]-\mathrm{I}^{-}$.

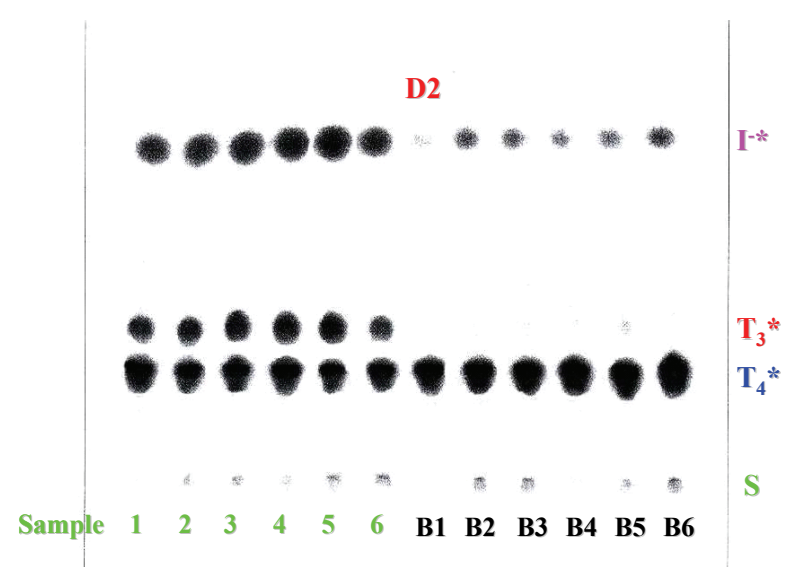

Fig. 4. Electronic image (made with BAS-5000 laser scanner) of radiochromatogram of incubation mixtures (Samples 1-6 and corresponding Blanks B1-B6) in iodothyronine deiodinase D2 assay. The radioactively labeled substrate was $\left[{ }^{125} \mathrm{I}\right]-\mathrm{T}_{4}$ and labeled products of its enzymatic conversion were $\left[{ }^{125} \mathrm{I}\right]-\mathrm{T}_{3}$ and $\left[{ }^{125} \mathrm{I}\right]-\mathrm{I}^{-} ; \mathrm{S}$ starting points.

\section{Radiometric assays for THs-conjugating enzymes}

In addition to the stepwise monodeiodinations of iodothyronines (see above), a number of other metabolic transformations of iodothyronine molecules have been described, in which several enzymes in peripheral tissues are engaged. The most important of these are conjugation of phenolic hydroxyl group of THs, either with uridine 5'-diphosphoglucuronic acid or sulfoconjugation (Braverman and Utiger 1996) (Fig. 1). The endogenous source of sulfate groups for sulfoconjugation is the "active sulfate", 3'-phosphoadenosine 5'-phosphosulfate. The respective enzymes are iodothyronine sulfotransferases (ST); the preferred substrate for $\mathrm{ST}$ is $\mathrm{T}_{3}$. Uridine 5'-diphospho-glucuronyltransferase (UDP-GT) prefers as a substrate $\mathrm{rT}_{3}$. Both glucuronide conjugation and sulfate conjugation occur in a number of tissues. The former occurs primarily in the liver microsomes and the latter in the kidney and liver cytosols.

Thyroid hormones can modulate concentration of neurotransmitters and metabolites in the CNS and receptor binding site numbers (Halbreich 1997). THs are supposed to control in this way the activity of some neurotransmitters (e.g. serotonin), which are hypothetically involved in the pathogenesis of depressive illness. On the other hand, many clinical studies indicated that various antidepressant treatments might influence the effects of hormones of hypothalamic-pituitary-thyroid axis in depressed patients. For example, Baumgartner et 
al. (1994) observed that subchronic administration of non-tricyclic antidepressant fluoxetine (Fluox) to the rats produced significant effects in the enzyme activities of all three known IDs in specific regions of the brain. Fluox belongs to the group of selective serotonin reuptake inhibitors and is the most frequently used drug today for the treatment of episodic depression. It is important that inadequate activities of brain IDs can lead to local insufficient $\mathrm{T}_{3}$ concentration and might be, therefore, one of the pathogenetic factors of depression.

Recently, we followed the influence of subchronic administration of Fluox (by itself or in combination with $\mathrm{T}_{3}$ ) to Wistar rats (for 25 days) on the metabolism of THs in different rat tissues (Pavelka 2010b). We used the adapted radiometric enzyme assays for UDP-GT and ST for the assessment of the effects of Fluox on potential induction of UDP-GT and/or ST enzyme activities in the rat liver. To detect changes in the IDs activities in the brain and pituitary, we also employed our newly developed radiometric assays for IDs of types 1, 2 and 3 (see above) (Pavelka 2010a). With the adapted radiometric assay for UDP-GT (Beestra et al. 1991), we measured the rate of conjugation of the phenolic hydroxyl group of L-3,3', 5' - [ $\left.{ }^{125} \mathrm{I}\right]$-triiodothyronine ([ $\left.\left.{ }^{125} \mathrm{I}\right]-\mathrm{rT}_{3}\right)$ with uridine 5'-diphosphoglucuronic acid (UDPGA), catalyzed by the UDP-GT in rat liver microsomes (Pavelka 2010b). Reaction mixtures containing UDPGA, the substrate $\left.{ }^{125} \mathrm{I}\right]-\mathrm{rT}_{3}$ and samples of microsomes, were analyzed after the incubation for $60 \mathrm{~min}$ at $37^{\circ} \mathrm{C}$ by ion-exchange chromatography on microcolumns of lipophilic Sephadex LH-20 (Fig. 5). The basis for radiometric determination of the ST enzyme activities in liver and kidney cytosolic fractions (Kaptein et al. 1997) was the transfer of sulfonate moiety from the "active sulfate", 3'-phosphoadenosine 5'-phosphosulfate (PAPS), to the substrate L-3,3',5-[ $\left.{ }^{125} \mathrm{I}\right]$-triiodothyronine $\left(\left[{ }^{125} \mathrm{I}\right]-\mathrm{T}_{3}\right)$. The extent of conversion of the substrate was determined by the measurement of ${ }^{125} \mathrm{I}$ radioactivity in eluted fractions after the separation of the sulfated, more polar product $\left[{ }^{125} \mathrm{I}\right]-\mathrm{T}_{3}-\mathrm{S}$, from the unmodified non-polar substrate $\left[{ }^{125} \mathrm{I}\right]-\mathrm{T}_{3}$, again by chromatography of the incubated reaction mixtures on microcolumns of Sephadex LH-20 (Pavelka 2010b).

The elaborated radiometric assay for UDP-GT was usable for the assessment of enzymatic conversion of radiolabeled unconjugated substrate $\left[{ }^{125} \mathrm{I}\right]-\mathrm{rT}_{3}$ to conjugated product $\left[{ }^{125} \mathrm{I}\right]-\mathrm{rT}_{3}$-glucuronide. We found about two-fold higher UDP-GT enzyme activities in samples of liver microsomes of rats treated with Fluox, in comparison with control rats. In contrast, the radiometric determination of ST activities in liver and kidney cytosolic fractions did not demonstrate any significant effects of the administration of Fluox, alone or together with $\mathrm{T}_{3}$, on the induction of these enzymes.

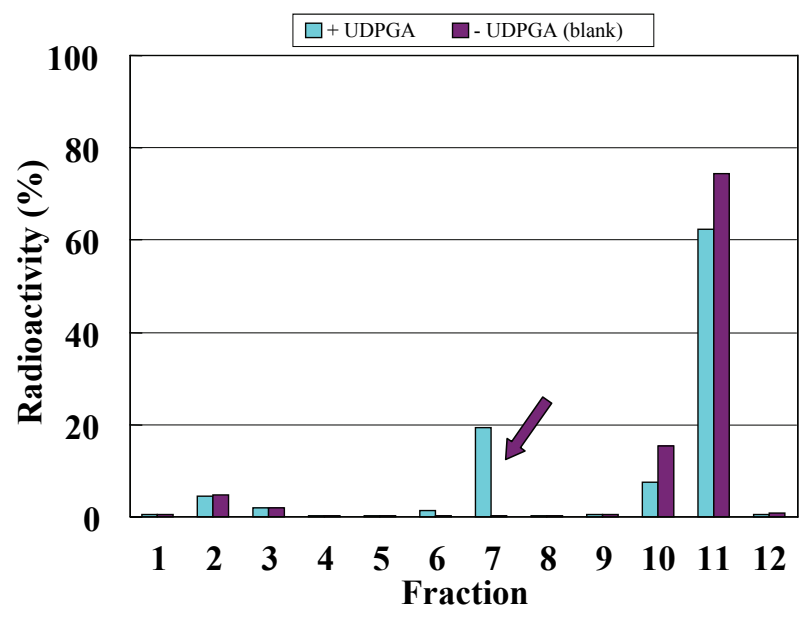

Fig. 5. Radiometric enzyme assay for UDP-GT with the substrate $\left[{ }^{125} \mathrm{I}\right]-\mathrm{rT}_{3}$. Sephadex LH-20 column chromatography: elution of $\left[{ }^{125} \mathrm{I}\right]$-iodide (fractions $2+3$ ), conjugated $\left.{ }^{[25} \mathrm{I}\right]-\mathrm{rT}_{3}$-glucuronide (fractions $6+7$ ) and unconjugated $\left[{ }^{125} \mathrm{I}\right]-\mathrm{rT}_{3}$ (fractions $10+11$ ).

\section{Modulation of D1 enzyme activity in murine white adipose tissue by leptin administration}

White adipose tissue (WAT) represents an important target for THs (Yen 2001, Obregon 2008, Ortega et al. 2012) which, together with a sympathetic nervous system, became the most important central regulators of energy balance and thermogenesis in homeothermic animals (Silva 2006). One of the most important signaling molecules secreted by adipose tissue is the hormone leptin (Macek-Jílková et al. 2010). THs and leptin may share some common downstream action sites and could act additively, although independently, to enhance energy expenditure (Wang et al. 2000). However, especially in WAT, the possible interplay between THs and leptin in the control of metabolism and weight of the tissue remains to be better characterized.

Using our newly developed radiometric enzyme assays (Pavelka 2010a), we studied (Macek-Jílková et al. 2010) possible changes in activities of the key THs-metabolizing enzymes, IDs of types 1, 2 and 3 in murine adipose tissue under the conditions that promoted either tissue hypertrophy (obesogenic treatment) or involution (caloric restriction), and in response to leptin. To assess the changes in activities of IDs in adipose 
tissue in response to the tissue enlargement, we evaluated the effect of feeding a special high-fat (HF) diet (containing 15\%, 59\%, and $26 \%$ calories in the form of protein, fat, and carbohydrate, respectively), which is known to induce obesity in C57BL/6J mice. Specific activity of D1 increased in both examined white fat depots (subcutaneous and visceral) in response to the HF diet. The strongest effect ( $\sim 3.4$-fold induction) was on epididymal fat after eight weeks feeding the HF diet, while after two weeks, the stimulation was only observed in dorsolumbar but not in epididymal fat (not shown). On the other hand, this dietary treatment had no effect on specific D1 and D2 activities in interscapular brown adipose tissue. Compared with D1, specific enzyme activities of both D2 and D3 in white fat depots were $\sim 50$-fold (epididymal fat) to $\sim 100$-fold (dorsolumbar fat) lower and did not change in response to the HF diet. Plasma concentration of leptin increased significantly after two weeks of HF feeding, and after eight weeks, leptin levels were even more elevated. An increase in D1 specific enzyme activity in WAT positively correlated with increasing plasma leptin levels (Fig. 6). To find out whether the HF diet-induced elevation of D1 activity in WAT could be reversed when fat accumulation is compromised without changing the diet composition, a mild $(10 \%)$ caloric restriction was applied in adult C57BL/6J mice fed the HF diet (HF-CR mice). Compared with ad libitum fed mice (HF-AL), a fiveweek-caloric restriction in HF-CR mice resulted in a reduction of body weight gain, a decrease in the weight of adipose tissue depots, and the reversal of adipocytes hypertrophy in epididymal fat pad. The HF-CR mice exhibited $\sim 2.0$-fold lower specific activity of D1 in epididymal WAT, in comparison with the HF-AL mice. In association with the changes in white fat content, plasma leptin levels were significantly reduced by caloric restriction. The above results suggest that D1 activity in white fat could be increased by leptin secreted from hypertrophic adipocytes. To verify this hypothesis, mice weaned to the standard low-fat (LF) diet (containing $25 \%, 9 \%$, and $66 \%$ calories in the form of protein, fat, and carbohydrate, respectively) were repeatedly injected with leptin or saline in the course of two weeks after the weaning. D1 activity was evaluated in epididymal fat $16 \mathrm{~h}$ after the last leptin injection. As expected, leptin injections increased D1 activity in WAT (Fig. 6). The fact that leptin stimulated D1 activity is in accordance with the leptin action in some other tissues, such as the liver, pituitary and thyroid gland (Araujo et al. 2009).
Regarding the broad range of substrates metabolized by $\mathrm{D} 1$, with only $\mathrm{T}_{3}$ representing a well established biologically active product of the deiodination reaction, the physiological role of D1 in white fat remains to be established.

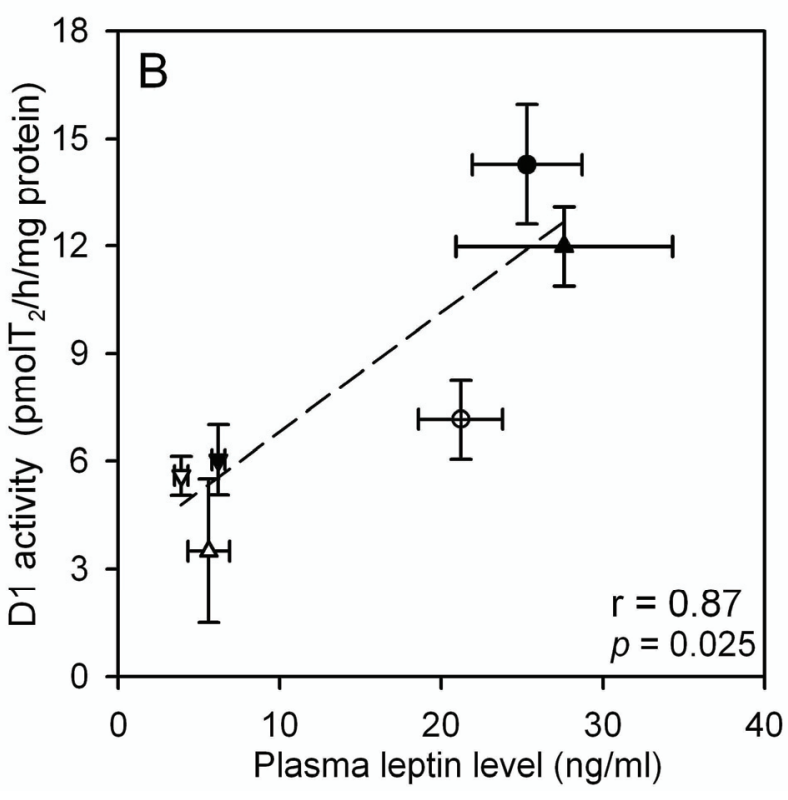

Fig. 6. Correlation of the white adipose tissue D1 activity (two weeks, $n=14-17$; eight weeks $n=6-8$ ) and plasma leptin levels $(n=7-8)$. Epididymal fat at two (triangle down) and eight weeks (triangle up) from mice fed high-fat (HF) (black) or low-fat (LF) diet (white), following the obesogenic treatment protocol; epididymal fat from the high-fat-ad libitum (HF-AL) mice (black circle) and high-fat-caloric-restriction (HF-CR) mice (crossed circle), following the caloric restriction treatment protocol. Data are means \pm SEM.

\section{Conclusions}

Correct assay conditions for the radiometric determination of the enzyme activity of the key enzyme of THs biosynthesis, thyroid peroxidase (TPO), have been established. The use of the adapted radiometric assay revealed a divergent influence of similar presumed goitrogenic agents, excessive exogenous bromide and perchlorate ions, on the TPO activity in the rat thyroids.

Novel radiometric methods for extremely sensitive determination of enzyme activities of all three types of iodothyronine deiodinases (IDs) in microsomal fractions of different rat and human tissues, as well as in homogenates of cultured mammalian cells were developed. The elaborated methods proved to be extremely sensitive, enabling to determine IDs enzyme activities as low as $10^{-18}$ katals. At the same time, the assays were rapid, reliable and robust. 
The elaborated radiometric enzyme assays for iodothyronine sulfotransferases (ST) and uridine 5'-diphospho-glucuronyltransferase (UDP-GT) were usable for the measurement of enzymatic conversion of radiolabeled unconjugated substrates $\left[{ }^{125} \mathrm{I}\right]-\mathrm{T}_{3}$ and $\left[{ }^{125} \mathrm{I}\right]-\mathrm{rT}_{3}$ to conjugated products $\left[{ }^{125} \mathrm{I}\right]-\mathrm{T}_{3}$-sulfate and $\left[{ }^{125} \mathrm{I}\right]-\mathrm{rT}_{3}$-glucuronide, respectively. Using these assays for the determination of specific activities of iodothyronine conjugating enzymes, we found about twofold higher UDP-GT activities in samples of liver microsomes of rats treated with fluoxetine (Fluox), in comparison with control rats. In contrast, the radiometric determination of ST activities in liver and kidney cytosolic fractions did not demonstrate any significant effects of the administration of Fluox, alone or together with $\mathrm{T}_{3}$, on the induction of these enzymes.

The results of determination of possible changes in IDs activities in murine adipose tissue under the conditions that promoted either tissue hypertrophy (obesogenic treatment) or involution (caloric restriction), and in response to leptin, obtained using our newly developed radiometric enzyme assays for IDs demonstrate, for the first time, an increase in D1 activity in WAT under the obesogenic treatment of mice and a decrease under caloric restriction. At the same time, a stimulatory effect of leptin on D1 activity in WAT was proved. Our results suggest that D1 has a functional role in WAT, with D1 possibly being involved in the control of adipose tissue metabolism and/or accumulation of the tissue.

\section{Conflict of Interest}

There is no conflict of interest.

\section{Acknowledgements}

Supported by the MSMT 7AMB 12SK158 grant, the Czech Science Foundation (GA CR grant No. 304/08/0256) and by the Academy of Sciences of the Czech Republic Research project RVO 67985823 (AV0Z 50110509).

\section{References}

ARAUJO RL, ANDRADE BM, DA SILVA ML, FERREIRA AC, CARVALHO DP: Tissue-specific deiodinase regulation during food restriction and low replacement dose of leptin in rats. Am J Physiol 296: E1157-E1163, 2009.

BAUMGARTNER A, DUBEYKO M, CAMPOS-BARROS A, ERAVCI M, MEINHOLD H: Subchronic administration of fluoxetine to rats affects triiodothyronine production and deiodination in regions of the cortex and in the limbic forebrain. Brain Res 635: 68-74, 1994.

BEETSTRA JB, VAN ENGELEN JGM, KARELS P, VAN DER HOEK HJ, DE JONG M, DOCTER R, KRENNING EP, HENNEMANN G, BROUWER A, VISSER TJ: Thyroxine and 3,3',5-triiodothyronine are glucuronidated in rat liver by different uridine diphosphate-glucuronyltransferases. Endocrinology 128: 741-746, 1991.

BRAVERMAN LE, UTIGER RD (eds): Werner and Ingbar's the Thyroid. A Fundamental and Clinical Text. 7th edn, Lippincott-Raven Publishers, New York, 1996.

HALBREICH U: Hormonal intervention with psychopharmacological potential: an overview. Psychopharmacol Bull 33: 281-286, 1997.

KAPTEIN E, VAN HAASTEREN GAC, LINKELS E, DE GREEF WJ, VISSER TJ: Characterization of iodothyronine sulfotransferase activity in rat liver. Endocrinology 138: 5136-5143, 1997.

KOHRLE J: Iodothyronine deiodinases. Methods Enzymol 347: 125-167, 2002.

KOPECKÝ J, ROSSMEISL M, FLACHS P, BRAUNER P, ŠPONAROVÁ J, MATĚJKOVÁ O, PRAŽÁK T, RŮŽIČKOVÁ J, BARDOVÁ K, KUDA O: Energy metabolism of adipose tissue-physiological aspects and target in obesity treatment. Physiol Res 53 (Suppl 1): S225-S232, 2004.

LEONARD JL, KOHRLE J: Intracellular pathways of thyroid hormone metabolism. In: Werner and Ingbar's the Thyroid. A Fundamental and Clinical Text. BRAVERMAN LE, UTIGER RD (eds), 8th edn, Lippincott Williams \& Wilkins, Philadelphia, 2000, pp 136-173.

MACEK JÍLKOVÁ Z, PAVELKA S, FLACHS P, HENSLER M, KŮS V, KOPECKÝ J: Modulation of type I iodothyronine 5'-deiodinase activity in white adipose tissue by nutrition: Possible involvement of leptin. Physiol Res 59: 561-569, 2010. 
NAKASHIMA T, TAUROG A: Improved assay procedures for thyroid peroxidase: application to normal and adenomatous human thyroid tissue. Clin Chim Acta 83: 129-140, 1978.

OBREGON MJ: Thyroid hormone and adipocyte differentiation. Thyroid 18: 185-195, 2008.

ORTEGA FJ, JÍLKOVÁ ZM, MORENO-NAVARRETE JM, PAVELKA S, RODRIGUEZ-HERMOSA JI, KOPECKÝ J, FERNÁNDEZ-REAL JM: Type I iodothyronine 5'-deiodinase mRNA and activity is increased in adipose tissue of obese subjects. Int J Obesity 36: 320-324, 2012.

PAVELKA S: Metabolism of bromide and its interference with the metabolism of iodine. Physiol Res 53 (Suppl 1): S81-S90, 2004.

PAVELKA S: Iodine transfer through mother's milk: the influence of bromide. In: Comprehensive Handbook of Iodine. Nutritional, Biochemical, Pathological and Therapeutic Aspects. PREEDY VR, BURROW GN, WATSON RR (eds), Academic Press, Oxford, 2009a, pp 199-206.

PAVELKA S: Bromide interference with iodine metabolism: goitrogenic and whole-body effects of excessive inorganic bromide in the rat. In: Comprehensive Handbook of Iodine. Nutritional, Biochemical, Pathological and Therapeutic Aspects. PREEDY VR, BURROW GN, WATSON RR (eds), Academic Press, Oxford, 2009b, pp 587-595.

PAVELKA S: Radiometric enzyme assays: development of methods for extremely sensitive determination of types 1, 2 and 3 iodothyronine deiodinase enzyme activities. J Radioanal Nucl Chem 286: 861-865, 2010a.

PAVELKA S: ${ }^{125}$ I-labelled iodothyronines: useful tools for studies of effects of an antidepressant drug fluoxetine in the rat. J Radioanal Nucl Chem 286: 867-871, 2010 b.

PAVELKA S: Radioiodine tracers as useful tools in studies of thyrotoxic effects of exogenous bromide and perchlorate ions. J Radioanal Nucl Chem 291: 405-408, 2012.

PAVELKA S, KOPECKÝ P, BENDLOVÁ B, ŠTOLBA P, VÍTKOVÁ I, VOBRUBA V, PLAVKA R, HOUŠTĚK J, KOPECKÝ J: Tissue metabolism and plasma levels of thyroid hormones in critically ill very premature infants. Pediatr Res 42: 812-818, 1997.

PAVELKA S, VOBECKÝ M, BABICKÝ A: Halogen speciation in the rat thyroid: simultaneous determination of bromine and iodine by short-term INAA. J Radioanal Nucl Chem 278: 575-579, 2008.

SILVA JE: Thermogenic mechanisms and their hormonal regulation. Physiol Rev 86: 435-464, 2006.

TAUROG A, DORRIS ML: Peroxidase-catalyzed bromination of tyrosine. Arch Biochem Biophys 287: 288-296, 1991.

VAN LEEUWEN FXR, HANEMAAIJER R, LOEBER JG: The effect of sodium bromide on thyroid function. Arch Toxicol 12 (Suppl): 93-97, 1988.

WANG JL, CHINOOKOSWONG N, YIN S, SHI ZQ: Calorigenic actions of leptin are additive to, but not dependent on, those of thyroid hormones. Am J Physiol 279: E1278-E1285, 2000.

YEN PM: Physiological and molecular basis of thyroid hormone action. Physiol Rev 81: 1097-1142, 2001. 